\title{
Physical modelling of the Akkajaure reservoir
}

\author{
J. Sahlberg \\ Swedish Meteorological and Hydrological Institute, SE-601 76 Norrköping, Sweden \\ Email: Jorgen.Sahlberg@smhi.se
}

\begin{abstract}
This paper describes the seasonal temperature development in the Akkajaure reservoir, one of the largest Swedish reservoirs. It lies in the headwaters of the river Luleälven in northern Sweden; it is $60 \mathrm{~km}$ long and $5 \mathrm{~km}$ wide with a maximum depth of $92 \mathrm{~m}$. The maximum allowed variation in surface water level is $30 \mathrm{~m}$. The temperature field in the reservoir is important for many biochemical processes. A one-dimensional lake model of the Akkajaure reservoir is developed from a lake model by Sahlberg (1983 and 1988). The dynamic eddy viscosity is calculated by a two equation turbulence model, a $k-\varepsilon$ model and the hypolimnic eddy diffusivity formulation which is a function of the stability frequency (Hondzo et al., 1993). A comparison between calculated and measured temperature profiles showed a maximum discrepancy of $0.5-1.0^{\circ} \mathrm{C}$ over the period 1999-2002. Except for a few days in summer, the water temperature is vertically homogeneous. Over that period of years, a weak stratification of temperature occurred on only one to two weeks a year on different dates in July and August. This will have biological consequences.
\end{abstract}

Keywords: temperature profile, reservoir, 1-D lake model, stratification. Sweden

\section{Introduction}

The thermal structure of lakes and reservoirs is determined by heat exchange through the surface and bottom boundaries and by the absorption of short wave radiation; heat transfer in the water occurs by mixing and advection. In northern Sweden, the lakes and reservoirs are ice covered for approximately six months each year, (Eklund, 1998). The ice cover isolates and insulates the water from heat exchange with the atmosphere and from wind-induced mixing. The mean water temperature is lowest when ice is forming. In winter, the heat lost through the ice-water interface is normally less than that gained from the sediments and the insolation through the snow and ice cover, (Bengtsson and Svensson, 1996). The mean temperature under the ice increases slowly until spring when insolation heats the surface water close to the ice. The temperature under the ice may even exceed the temperature of maximum density which implies that the short wave heat input is greater than the vertical heat exchange in the surface layer, (Sahlberg, 1988). A large increase in temperature occurs when the ice breaks up, normally in early June, and continues until August; cooling thereafter leads to new ice formation at the end of November or early December.
This work investigated the temperature conditions of the Akkajaure reservoir, the second largest reservoir in Sweden after Lake Vänern, in the headwaters of the River Luleälven which is the largest electricity producing river in Sweden. Akkajaure is regulated to a maximum surface water level amplitude of $30 \mathrm{~m}$.

To explore whether Akkajaure develops a thermocline, temperature and chemistry were measured in the summers 1999-2001 and the reservoir proved to be cold and almost vertically homogeneous. Transistor temperature recordings in Lake Torne Träsk in the summer of 2002 showed a similar vertical temperature structure which varied linearly from a surface temperature of $9-10^{\circ} \mathrm{C}$ to $5-6^{\circ} \mathrm{C}$ at a depth of $70 \mathrm{~m}$. In a study on the Eklutna Reservoir in Alaska, Gosink (1987) found a thermocline at a depth of 5-10 $\mathrm{m}$ where the summer surface temperature was $13^{\circ} \mathrm{C}$ and the bottom temperature, at $50 \mathrm{~m}$ depth, was $6^{\circ} \mathrm{C}$. In Sweden, Eklund (1998) and Moberg (1981) found that Lakes Tängvattnet, Saggat and Gussvattnet experienced similar summer temperature profiles similar to those in the Eklutna reservoir with $12-14^{\circ} \mathrm{C}$ at the surface and $6-7^{\circ} \mathrm{C}$ at depths of $50-60 \mathrm{~m}$.

Is Akkajaure, with its large maximum depth of almost $100 \mathrm{~m}$, vertically homogeneous, or is it stratified during 
different periods in the summer? Is it the high latitude in combination with a long ice covered season and the harsh weather conditions of northern Sweden that mainly controls the reservoir dynamics? Does the large regulation affect the stratification?

\section{Hydrology}

The annual variation in discharge of the Akkajaure catchment is at a maximum in May and June following snow and glacier melt while, in autumn, peaks occur after heavy rainfalls. The spring melt water fills the Akkajaure reservoir from the low winter level to a level close to the maximum permitted. As well as affecting the Akkajaure heat balance, this filling by meltwater transports substantial amounts of suspended material into the reservoir; this, among other things, changes the extinction coefficient of the water and, thus, the light absorption profile.

To estimate the temporal and spatial distribution of the discharge, the HBV hydrological model, (Lindström et al., 1997) has been calibrated to the Akkajaure drainage basin.

\section{THE DRAINAGE BASIN}

Akkajaure lies in the headwaters of the River Luleälven and its drainage basin covers $4650 \mathrm{~km}^{2}$ at a mean height of $825 \mathrm{~m}$ a.s.l. (Fig. 1) The maximum dam level is 453 m.a.s.l. and the corresponding water area is $266 \mathrm{~km}^{2}$. It is heavily regulated with a maximum allowed surface water level amplitude of $30 \mathrm{~m}$. In addition to the discharge to Akkajaure from its own catchment, there is a tunnel inflow from the Sitasjaure dam through the Ritsem power station. This tunnel, which is $16.3 \mathrm{~km}$ long, enters Akkajaure at levels from 436 to $440 \mathrm{~m}$ a.s.l. The land cover in the catchment is $82 \%$ open land, $4 \%$ forests and $14 \%$ lakes and the Akkajaure reservoir. Ten different inflow rivers, of which Vuojatätno is the largest, flow into Akkajaure. Of the total inflow, approximately $55 \%$ comes from the Vuojatätno, $20 \%$ from the Sitasjaure tunnel and the remaining $25 \%$ from the rest of the catchment.

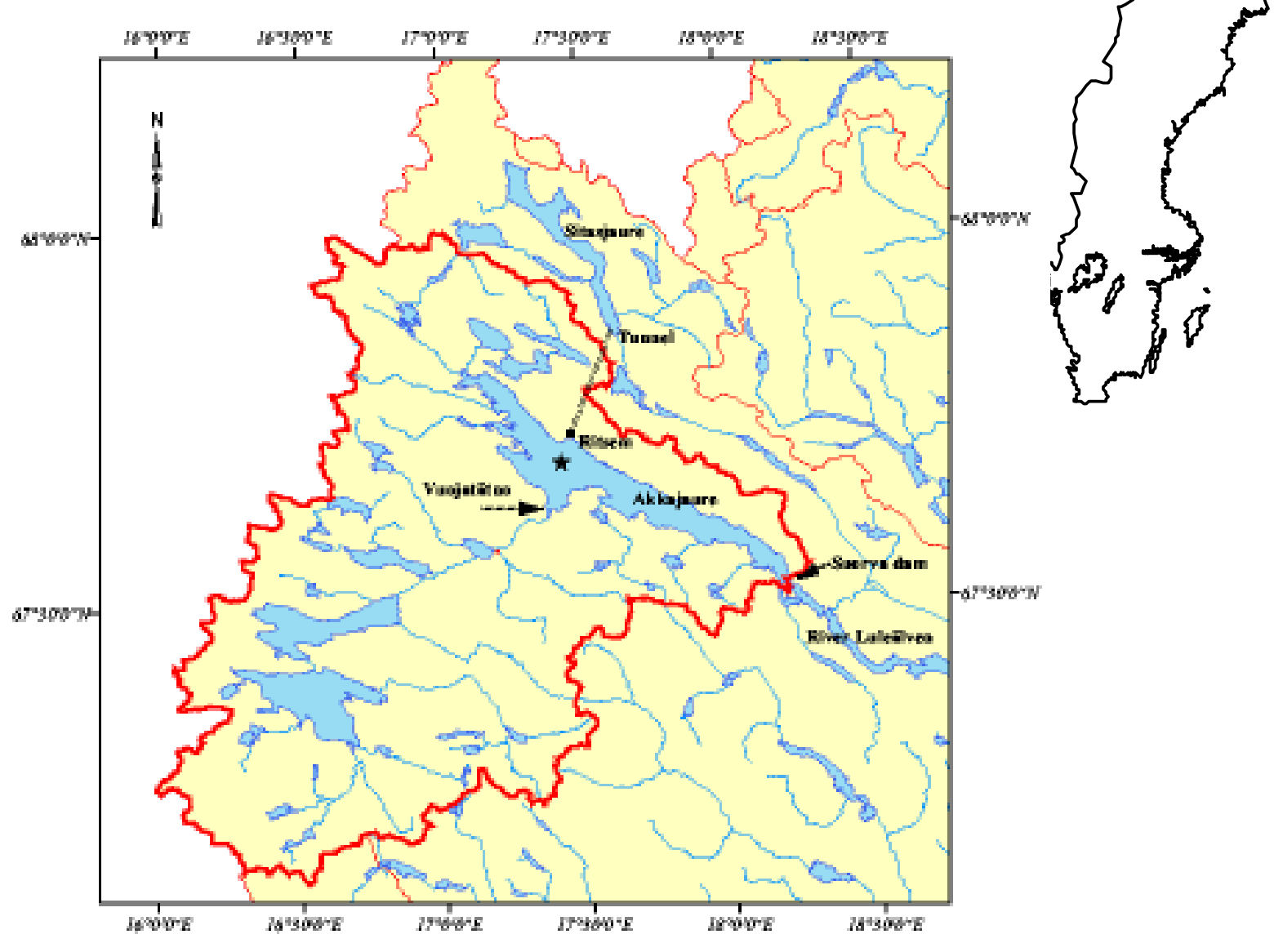

Fig. 1. The Akkajaure drainage basin, marked with an arrow on the map of Sweden, is shown with the thick red line. The temperature measuring station in Akkajaure is marked with a star. 


\section{MODEL APPLICATION AND CALIBRATION}

The HBV model has to be calibrated against measured time series of runoff, using the calculated inflow, $Q_{\text {rec }}$, based on measurements of the outflow through the Suorva dam, $Q_{\text {out }}$, the tunnel flow from the Sitasjaure dam, $Q_{\text {tun }}$, and the storage change in Akkajaure, $\frac{\partial V_{v o l}}{\partial t}$.

$$
Q_{\text {rec }}=\frac{\partial V_{\text {vol }}}{\partial t}-Q_{\text {tun }}+Q_{\text {out }}
$$

While the water level in Akkajaure is regulated to vary by no more than $30 \mathrm{~m}$, during the years 1998-2002, the maximum change was $15 \mathrm{~m}$. The water level is measured once a day near the dam; the increase over the mean water level due to the mean wind velocity of $3 \mathrm{~m} \mathrm{~s}^{-1}$ over the extent of the reservoir might create a steady state water level difference of $0.005 \mathrm{~m}$ (U.S Army, 1977), so the accuracy of the measured water level is assumed to be to $0.005 \mathrm{~m}$. All the data on air temperature, precipitation, and $Q_{\text {rec }}$ have been taken from data bases at SMHI along with land use information. The calibration had an $\mathrm{R}^{2}$ value of 0.927 so the HBV model describes the discharge to Akkajaure very well.

\section{RUNOFF SIMULATION}

The simulation of total discharge from 1st October 1997 to 1 st October 2002 is exemplified for the years 1998-2002 in Fig. 2. The maximum inflow of $986 \mathrm{~m}^{3} \mathrm{~s}^{-1}$ is in June 2002 while the minimum of $30 \mathrm{~m}^{3} \mathrm{~s}^{-1}$ occurs in winter when all precipitation falls as snow. Large variations in discharge in autumn and winter depend on the inflow from the Sitasjaure tunnel which is regulated.

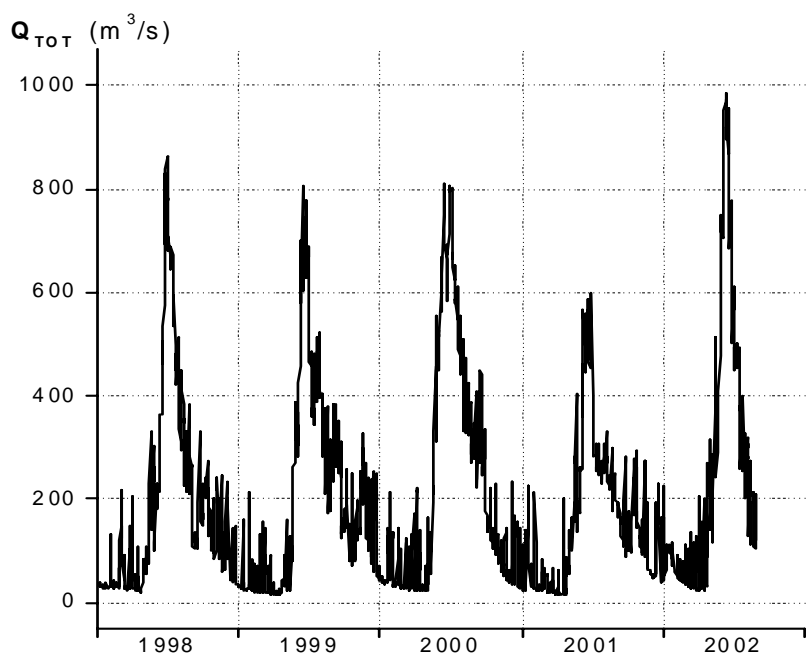

Fig. 2. The total discharge, including the Sitasjaure tunnel, to Akkajaure from 1998 to 2002

\section{The lake model}

\section{THE AKKAJAURE RESERVOIR}

Since the 1890 s, electricity has been transferred over long distances without excessive energy losses so the large waterfalls in the River Luleälven were exploited for electric power generation. To guarantee a large minimum water supply to the power stations, dams were built all along the river (Forsgren, 1989). The largest dam is the Suorva dam which controls Akkajaure. The first Suorva dam was built 1919-1923. Six headwater lakes to the river Luleälven are then linked to the Akkajaure reservoir with a total surface area of $150 \mathrm{~km}^{2}$. In the three reconstruction periods that followed, the volume of the reservoir increased more then five times and the surface area was almost doubled (Table 1).

Unfortunately, there is no complete hypsographic curve over the reservoir. The main interest so far has been in the volume curve for power regulation which covers only the interval between minimum and maximum pool elevation i.e. the upper $30 \mathrm{~m}$ of the reservoir. However, an approximate hypsographic curve (Fig. 3) based on the existing volume curve has been constructed using some GPS-based echo sounding in the summers of 1999 and 2000. The maximum depth is $92 \mathrm{~m}$ (SMHI, 1996), and the mean depth, calculated from the hypsographic curve, is approximately $30 \mathrm{~m}$.

\section{THE 1-D MODEL}

A one-dimensional lake model, based on the $k-\varepsilon$ turbulence model (Rodi, 1980) and the equation solver Probe (Svensson, 1998), is focussed on the heat balance, as a further development of the lake model of Sahlberg (1983

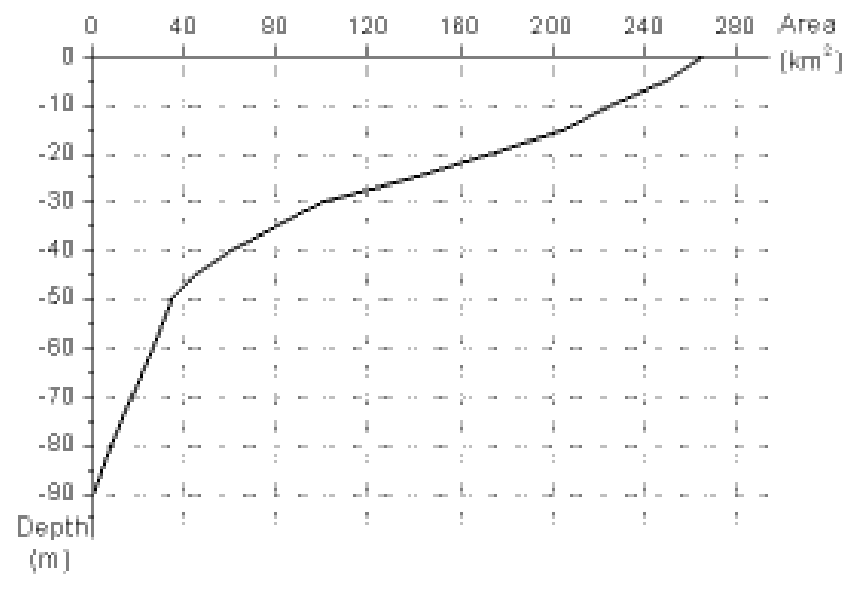

Fig. 3. The hypsographic curve of the Akkajaure reservoir 
Table 1. The Akkajaure reservoir data.

\begin{tabular}{lllll}
\hline Dam construction year & $1919-1923$ & $1937-1941$ & $1942-1944$ & 1966-1972 \\
\hline Max. regulated volume & $1020 * 10^{6} \mathrm{~m}^{3}$ & $2190 * 10^{6} \mathrm{~m}^{3}$ & $2750 * 10^{6} \mathrm{~m}^{3}$ & $5900 * 10^{6} \mathrm{~m}^{3}$ \\
Max. water level variation & $8.5 \mathrm{~m}$ & $15.3 \mathrm{~m}$ & $18.4 \mathrm{~m}$ & $30 \mathrm{~m}$ \\
Max. lake surface area & $150 \mathrm{~km}^{2}$ & $205 \mathrm{~km}^{2}$ & $220 \mathrm{~km}^{2}$ & $266 \mathrm{~km}^{2}$ \\
\hline
\end{tabular}

and 1988). The water balance in Akkajaure is governed by the inflow, which is the sum of the unregulated river inflows, the regulated discharge from the Sitasjaure tunnel and the outflow through the Suorva dam. The inflow levels are mainly close to the reservoir surface and the outflow is just below the minimum pool elevation. These flow conditions create vertical velocities in the reservoir. Thus, vertical velocity must be included in the momentum, heat and $k-\varepsilon$ equations.

Momentum equations :

$$
\begin{aligned}
& \frac{\partial \rho U}{\partial t}+W \frac{\partial \rho U}{\partial z}=-\frac{\partial P}{\partial x}+\frac{\partial}{\partial z}\left(\frac{\mu_{\text {eff }}}{\rho} \frac{\partial \rho U}{\partial z}\right) \\
& \frac{\partial \rho V}{\partial t}+W \frac{\partial \rho V}{\partial z}=-\frac{\partial P}{\partial y}+\frac{\partial}{\partial z}\left(\frac{\mu_{e f f}}{\rho} \frac{\partial \rho V}{\partial z}\right)
\end{aligned}
$$

where $t$ is time variable, $x$ and $y$ horizontal space coordinates, $z$ vertical space coordinate, $U$ and $V$ horizontal velocities, $W$ the vertical velocity (caused by in- and outflows at different levels in the reservoir), $P$ pressure and $\rho$ density. The dynamical effective viscosity, $\mu_{\text {eff }}$, is the sum of the turbulent viscosity, $\mu_{T}$, and the laminar viscosity, $\mu$. The Coriolis term has been excluded, because the Akkajaure is less than $10 \mathrm{~km}$ wide while the external Rossby radius is of the order $150 \mathrm{~km}$. When it comes to the internal Rossby radius, all measurements show that there is occasionally only weak density stratification in the reservoir and, thus, no significant internal waves.

Heat equation :

$$
\frac{\partial\left(\rho c_{p} T\right)}{\partial t}+W \frac{\partial\left(\rho c_{p} T\right)}{\partial z}=\frac{\partial}{\partial z}\left(\frac{\mu_{e f f}}{\rho \sigma_{e f f}} \frac{\partial\left(\rho c_{p} T\right)}{\partial z}\right)+F_{q}+F_{\text {sun }}
$$

where $T$ is the water temperature, $c_{p}$ is the specific heat of water, $\sigma_{\text {eff }}$ the effective Prandtl number which is the sum of the laminar and turbulent Prandtl numbers, $F_{q}$ is a source term due to the horizontal advection and $F_{\text {sun }}$ is a source term due to insolation. $F_{q}$ is given by

$$
F_{q}=\rho_{0} c_{p}\left(\frac{Q_{\text {in }} T_{\text {in }}}{\Delta V_{\text {in }}}-\frac{Q_{\text {out }} T}{\Delta V_{\text {out }}}\right)
$$

where $\rho_{0}$ is a reference density of water, $Q_{\text {in }}$ and $Q_{\text {out }}$ are volume fluxes of in- and outflowing water, $T_{i n}$ is the temperature of the inflowing water and $\Delta V_{\text {in }}$ and $\Delta V_{\text {out }}$ are the volumes of the grid cells at the in- and outflow levels respectively.

$F_{\text {sun }}$ is formulated as

$$
F_{\text {sun }}=F_{s}^{w}(1-\eta) e^{-\beta(D-z)}
$$

where $F_{s}^{w}$ is that part of the total insolation that penetrates the water surface, $\eta$ is the fraction of $F_{s}^{w}$ absorbed in the upper centimetre close to the water surface, $\beta$ is the extinction coefficient and D the total water depth (the $z$ axis starts at the bottom pointing upwards). The short wave radiation that penetrates the water surface, $F_{s}^{w}$, is given by

$$
F_{s}^{w}=F_{s}\left(1-\alpha_{w}\right)
$$

where $\alpha_{w}$ is the albedo of the water. If the reservoir is ice and snow covered, the formulation reads, $F_{s}^{i t}=F_{s}\left(1-\alpha_{s}\right)$ where $\alpha_{s}$ is the snow surface albedo. The short wave radiation that penetrates a snow and ice cover follows the formulation by Sahlberg (1988) and Omstedt and Axell (2003),

$$
F_{s}^{i b}=F_{s}^{i t} f_{s} f_{i} f_{e}
$$

where $F_{s}^{i b}$ is the short wave radiation at the ice-water interface, $f_{s}$ and $f_{i}$ are penetrating factors for snow and ice and $f_{e}$ is an extinction function.

The insolation through the atmosphere, $F_{s}$ is formulated according to Bodin (1979),

$$
F_{s}=\varepsilon_{t} S_{0} \cos \theta_{a}\left(f_{t}-f_{a}\right)\left(1-f_{c} n_{c}\right)
$$

where $\varepsilon_{t}$ is the atmospheric turbidity (constant 0.95 ), $S_{0}$ is the solar constant, $\theta_{a}$ is the zenith angle of the sun, $f_{t}, f_{a}$ and $f_{c}$ are transmission, absorption and cloud functions respectively and $n_{c}$ is the total cloud cover (0-1).

The dynamic eddy viscosity is calculated from the turbulent kinetic energy, $k$, and its dissipation rate, $\mathcal{E}$, by the Prandtl/Kolmogorov relation :

$$
\mu_{T}=C_{\mu} \rho \frac{k^{2}}{\varepsilon}
$$


where $C_{\mu}$ is an empirical constant.

The turbulent kinetic energy, $k$, is given by,

$$
\frac{\partial k}{\partial t}+W \frac{\partial k}{\partial z}=\frac{\partial}{\partial z}\left(\frac{\mu_{e f f}}{\rho \sigma_{k}} \frac{\partial k}{\partial z}\right)+P_{s}+P_{b}-\varepsilon
$$

where $\sigma_{k}$ is the Prandt1/Schmitt number fork $k$. $P_{s}$ and $P_{b}$ are production terms due to shear velocity and buoyancy.

The dissipation rate of turbulent kinetic energy, $\varepsilon$, becomes

$$
\frac{\partial \varepsilon}{\partial t}+W \frac{\partial \varepsilon}{\partial z}=\frac{\partial}{\partial z}\left(\frac{\mu_{e f f}}{\rho \sigma_{\varepsilon}} \frac{\partial \varepsilon}{\partial z}\right)+\frac{\varepsilon}{k}\left(C_{1 \varepsilon} P_{s}+C_{3 \varepsilon} P_{b}-C_{2 \varepsilon} \varepsilon\right)
$$

where $\sigma_{\varepsilon}$ is the Prandtl/Schmitt number for $\varepsilon, C_{1 \varepsilon}, C_{3 \varepsilon}$ and $C_{2 \varepsilon}$ are empirical constants.

The production terms due to shear velocities, $\mathrm{P}_{\mathrm{s}}$ and buoyancy, $\mathrm{P}_{\mathrm{b}}$, are given by

$$
\begin{aligned}
& P_{s}=\frac{\mu_{\text {eff }}}{\rho}\left[\left(\frac{\partial U}{\partial z}\right)^{2}+\left(\frac{\partial V}{\partial z}\right)^{2}\right] \\
& P_{b}=\frac{\mu_{\text {eff }}}{\rho} \frac{g}{\rho_{0}} \frac{\partial \rho}{\partial z}
\end{aligned}
$$

The effective dynamic viscosity, $\mathrm{m}_{\text {eff }}$, and effective Prandtl/Schmitt number, $\mathrm{s}_{\text {eff }}$, is written as

$$
\frac{\mu_{e f f}}{\sigma_{e f f}}=\frac{\mu}{\sigma}+\frac{\mu_{T}}{\sigma_{T}}
$$

A full description of the derivation of all turbulence equations and empirical coefficients is found in Rodi (1980) and Svensson (1998).

The surface boundary conditions for the momentum equations are defined as:

$$
\begin{aligned}
& \frac{\mu_{e f f}}{\rho} \frac{\partial(\rho U)}{\partial z}=\tau_{a x} \\
& \frac{\mu_{e f f}}{\rho} \frac{\partial(\rho V)}{\partial z}=\tau_{a y}
\end{aligned}
$$

where $\tau_{a x}=\rho_{a} C_{D} U_{a} W_{a}$ and $\tau_{a y}=\rho_{a} C_{D} V_{a} W_{a}$ are the wind stresses. Wind velocities in $\mathrm{x}$ (along lake) and $\mathrm{y}$ (across lake) direction are described by $U_{a}, V_{a}$ and $W_{a}=\left(U_{a}^{2}+V_{a}^{2}\right)^{1 / 2}$ is the total wind velocity. $C_{D}$ is the drag coefficient and $\rho_{a}$ is the air density. At the lower boundary, the condition of zero velocity is used.

For the heat equation, the surface boundary condition may be formulated as:

$$
\frac{\mu_{e f f}}{\rho \sigma_{e f f}} \frac{\partial \rho c_{p} T}{\partial z}=F_{n}
$$

where $F_{n}$ is the net heat exchange through the water surface. It is the sum of four heat fluxes

$$
F_{n}=F_{h}+F_{e}+F_{n l}+\eta F_{s}^{w}
$$

where $F_{h}, F_{e}, F_{n l}$ are the sensible and latent heat fluxes and net long wave radiation respectively and $\eta$ is the part of the short wave radiation that is absorbed at the water surface. A short description of these fluxes follows below. For a complete description see Omstedt and Axell (2003). During the winter season, the ice cover changes the surface boundary condition for the heat equation to zero at the icewater interface.

At the lower boundary, a zero flux condition is used, i.e. there is no sediment heat flux.

The sensible and latent heat fluxes follow the same type of formulation,

$$
\begin{aligned}
& F_{h}=\rho_{a} c_{p a} C_{H} W_{a}\left(T_{s}-T_{a}\right) \\
& F_{e}=\rho_{a} L_{e} C_{E} W_{a}\left(q_{s}-q_{a}\right)
\end{aligned}
$$

where $c_{p a}$ is the specific heat capacity of air, $C_{H}$ is the bulk coefficient for the sensible heat flux, $T_{s}$ is the surface water temperature, $T_{a}$ is the air temperature, $L_{e}$ is the latent heat of evaporation, $C_{E}$ is the bulk coefficient for the latent heat flux, $q_{s}$ is the specific humidity of air at the water surface, assumed to equal the saturation value at the temperature $T_{s}$ and $q_{a}$ is the specific humidity of air at the reference level. The net long wave radiation, $F_{n l}$, is the difference between upward and downward long wave radiation, according to Bodin (1979),

$$
F_{n l}=\varepsilon_{s} \sigma_{s} T_{s k}^{4}-\sigma_{s} T_{a k}^{4}\left(a_{1}+a_{2}\left(e_{a}\right)^{1 / 2}\right)\left(1+a_{3} n_{c}^{2}\right)
$$

where $\varepsilon_{s}$ is the emissivity of the water surface, $\sigma_{s}$ is StefanBolzman coefficient, $T_{s k}$ and $T_{a k}$ is the surface water and air temperature, $a_{1}, a_{2}$ and $a_{3}$ are constants and $e_{a}$ is the water vapour pressure in the atmosphere.

In these heat flux formulations, Eqns. (9), (20), (21) and (22) require as input only standard meteorological data available from synoptic weather stations.

The equation of state assumes a quadratic relationship between temperature and density,

$$
\rho=\rho_{o}\left(1-\alpha\left(T-T_{r}\right)^{2}\right)
$$

where $\rho_{o}$ is a reference density, $T_{r}$ the temperature of maximum density and $\alpha$ a constant.

Despite the fact that hypolimnion may be isolated from 
the surface layer by a thermocline, mixing events have been observed in the hypolimnion (Hondzo et.al., 1993). Hypolimnetic eddy diffusivity is commonly expressed as a function of the stability frequency $N^{2}$ according to:

$$
K_{z}=\alpha\left(N^{2}\right)^{-\gamma}
$$

where $N^{2}=-\frac{g}{\rho} \frac{\partial \rho}{\partial z}, g=$ acceleration of gravity, $\rho=$ water density. For many lakes $\gamma$ varies between 0.4 and 0.6 . From measurements in four northern Minnesota lakes Hondzo et al. (1993) found that $\alpha$ could be formulated as a function of the lake surface area and that a general expression for $K_{z}$ is :

$$
K_{z}=8.17 \times 10^{-8}\left(A_{s}\right)^{0.56}\left(N^{2}\right)^{-0.43}
$$

where $A_{s}=$ lake surface area. The maximum eddy diffusivity is obtained under very weak stratifications which is defined as $N^{2}=7.0 \times 10^{-5}$ (Riley and Stefan, 1987). The lake model uses this formulation of $K_{z}$ and adds it to the effective dynamic viscosity $\mu_{\text {eff }}$, calculated by the $k-\varepsilon$ model.

\section{ICE FORMATION, GROWTH AND MELTING}

In the present model, ice is formed when the temperature of the upper centimetres of the reservoir drops below the freezing point. The initial ice formation can be rather complex as ice formation and break up events depend on the heat loss and the wind stress at the surface. This is parameterised as follows. If the ice thickness is less the $0.1 \mathrm{~m}$ and the daily mean value of the wind velocity is greater then $4 \mathrm{~ms}^{-1}$, the ice cover will break up and disappear. When weather conditions allow the ice to grow thicker than $0.1 \mathrm{~m}$, the growth continues until the spring melting. The ice growth is calculated using a degree day method, Bengtsson and Eneris (1977),

$$
h_{\text {ice }}=K_{g}\left(\sum \bar{T}_{a}\right)^{1 / 2} \quad \text { if } \bar{T}_{a}<0
$$

where $h_{i c e}$ is the ice thickness, $K_{g}$ a constant with the value 0.024 and $\bar{T}_{a}$ the daily mean air temperature. The air temperature summation starts on the date of ice formation.

The ice melting formulation is taken from Ashton (1983), where the daily descreasing ice thickness is a linear function of $\bar{T}_{a}$,

$$
\Delta h_{i c e}=K_{m} \bar{T}_{a} \quad \text { if } \bar{T}_{a}>0
$$

where $K_{m}$ is put constant to $5.3 * 10^{-3}$.

The snow thickness on the ice is assumed to vary with the ice thickness. During ice growth, it is put to $h_{\text {snow }}=0.20 * h_{\text {ice }}$ and during melting $h_{\text {snow }}=0.05^{*} h_{\text {ice }}$.

\section{METEOROLOGICAL DATA}

The meteorological variables forcing the model are air temperature, wind velocity, total cloud cover and relative humidity. The wind data enter the stress functions and, thus, the boundary conditions to the momentum equations. All other data together with wind enter the heat flux equations which are the boundary conditions to the heat equation.

Of the two meteorological stations in the Akkajaure area, Ritsem and Stora Sjöfallet, Ritsem is the most representative because Stora Sjöfallet is in the southern part of Akkajaure where the valley is narrow and hence, wind velocities are probably higher. Ritsem from September 1997 is an automatic weather station which, unfortunately, does not measure cloud cover so cloud data had to be averaged from two manual stations, Katterjåkk and Kvikkjokk, respectively $80 \mathrm{~km}$ north and $80 \mathrm{~km}$ south of Akkajaure. All meteorological data were extracted every third hour from 1998-01-01 to 2002-10-01. Typical air temperatures in summer are $1-15^{\circ} \mathrm{C}$, while in winter temperatures often drop to $-20^{\circ} \mathrm{C}$. Almost all wind velocities are in the range $0-8 \mathrm{~m} \mathrm{~s}^{-1}$ with a mean value over the whole period of $2.9 \mathrm{~m} \mathrm{~s}^{-1}$. The maximum wind velocity, defined as the mean wind velocity measured over 10 minutes, is $18 \mathrm{~m} \mathrm{~s}^{-1}$ and occurred in early winter 2000 .

\section{Measurements}

\section{WATER TEMPERATURE MEASUREMENTS}

The quality of a model is judged by its ability to reproduce the temperature profiles measured in the reservoir. During the field experiments from 1999 to 2002, temperature profile measurements were made on nine different occasions along with water sampling for chemistry analysis. Some measurements were read manually from a water bucket thermometer and some were measured by a standard recording thermistor. However, no profile measurement includes the bottom water. In summer, 2002, two single thermistors, recording hourly, were placed in the outlets of the two main inflows to Akkajaure, Vuojatätno and the Sitasjaure tunnel.

Nevertheless, from the 1950 s to the 1970 s, over 23 years, winter and summer temperature profile measurements were made at Akkajaure, twice a year, normally in March along with ice thickness measurements, and in August. Both winter (wm) and summer (sm) mean temperature profiles have been calculated from these measurements so that typical winter and summer temperatures in Akkajaure are shown in Fig. 4. 

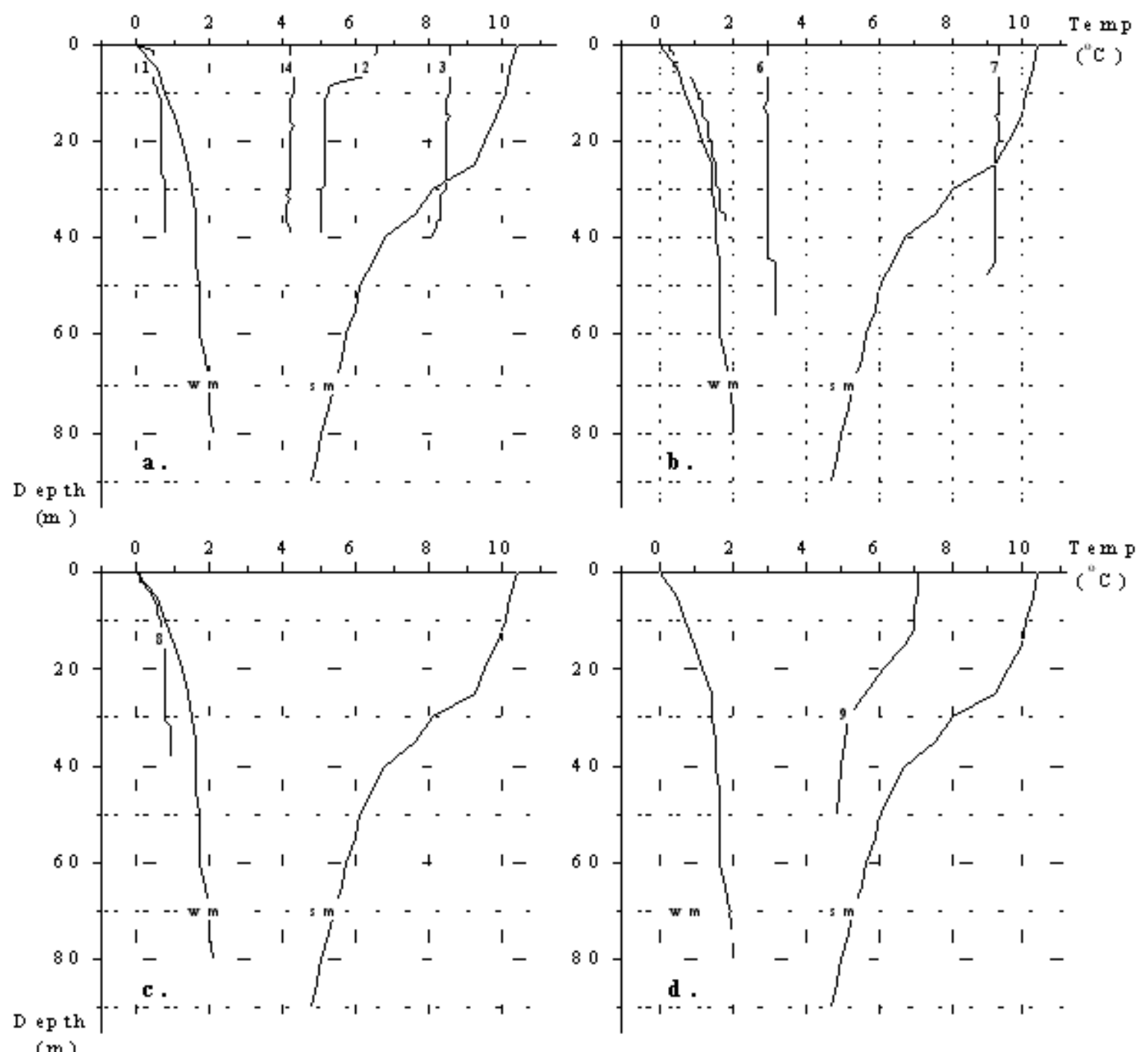

(m)

Fig. $4 a-d$. Measured temperature profiles in Akkajaure. From 1999 (a) at the following dates, 1=1999-04-27, $2=1999-06-20,3=1999$ 08-12, $4=1999-11-10$, from year 2000 (b), $5=2000-03-13,6=2000-06-14, \quad 7=2000-09-08$, from 2001 (c) $8=2001-04-02$ and from 2002 (d) $9=2002-06-24$. The old winter and summer mean temperature profiles are the thick black lines marked with wm and sm.

\section{LIGHT MEASUREMENTS}

The main heat flux through the water surface in spring and summer is short wave insolation. As it penetrates the water column, it is affected by the optical properties of the water. In 1999, light measurements were made in the water in the reservoir, every metre from the surface to a depth of $20 \mathrm{~m}$., on four occasions, April 26, June 28, August 11 and November 27; in April, the light was measured from the ice and on the other three occasions from a boat. An exponential curve, adjusted to the measured profiles with high $\mathrm{R}^{2}$ values (0.984-0.998), gives four extinction coefficients $0.24,0.34$, 0.32 and $0.25\left(\mathrm{~m}^{-1}\right)$. On April 26, the reservoir is still ice covered and the snowmelt in the catchment has yet to start.
A probable scenario of the extinction coefficient variation in Akkajaure is the following. The value of 0.24 is the lowest value measured in this year. As the snow starts to melt at the end of May, the discharge increases rapidly and transports suspended material into Akkajaure; this results in an increase in the extinction coefficient to 0.34 . Thereafter, the discharge, which peaks in late June and July, decreases slowly over the autumn and the suspended material sinks slowly to the bottom so that by November 27 , the extinction coefficient is down to 0.25 . The lake model uses a constant extinction coefficient of 0.24 under ice conditions and monthly values during the open water season are based on interpolated measurements. The importance of the extinction 
coefficient for temperature development in Akkajaure will be discussed later.

\section{ICE MEASUREMENTS}

No recent measurements of ice formation and thickness are available from Akkajaure but from 1950-1970, an ice thickness measurement were made once a year, normally in March. These measurements indicate a mean ice thickness of $0.80 \mathrm{~m}$ and range from $0.62-0.98 \mathrm{~m}$. However, ice measurements are still made $100 \mathrm{~km}$ north of Akkajaure in the unregulated Lake Torne Träsk, in volume terms the third largest lake in Sweden, $332 \mathrm{~km}^{2}$ in area with a mean depth of $52 \mathrm{~m}$ (SMHI, 1996) These ice measurements are used to verify the ice routines in the model, which have a large impact on the temperature profile. Ice formation dates in Akkajaure were, on average, $23 \pm 10$ days earlier than in Torne Träsk; the mean depth of Akkajaure when full is $30 \mathrm{~m}$, much less than the $52 \mathrm{~m}$ in Torne Träsk. A smaller mean depth implies faster cooling in autumn and early winter and, therefore, earlier ice formation.

\section{Results}

From 1st January 1998 to 30th September, 2002, lake model calculations in Akkajaure used a 10 minutes time step and a vertical resolution of $1 \mathrm{~m}$ over the whole water column except close to the surface, where the resolution is 0.25 to $0.5 \mathrm{~m}$. The weather forcing is updated every third hour. The catchment discharge and the tunnel inflow have a time resolution of one day. All solutions presented here are time step and grid independent and, therefore, represent the true solutions to the differential equations.

ICE

In an ice covered lake or reservoir, heat exchange with the atmosphere is reduced by the insulation afforded by the snow and ice cover. During the melting period, from April to June, the snow and ice melts under increasing insolation and the water temperature close to the ice-water interface increases due to the penetration of the insolation. Thermal convection begins close to the ice surface. As the insolation increases, the depth of the upper homogeneous layer increases. To perform simulations over several years, without any restarts, there must be, linked to the heat calculation model, an ice model which describes, correctly, the growth and decay of ice formation. The modelled ice thickness and break up data have also been compared to measurements from Torne Träsk (Fig. 5). Even though the ice formation dates differ between Akkajaure and Torne Träsk, both lakes reach approximately the same maximum ice thickness over the winter (Eklund, 1998). The old ice thickness measurements from Akkajaure

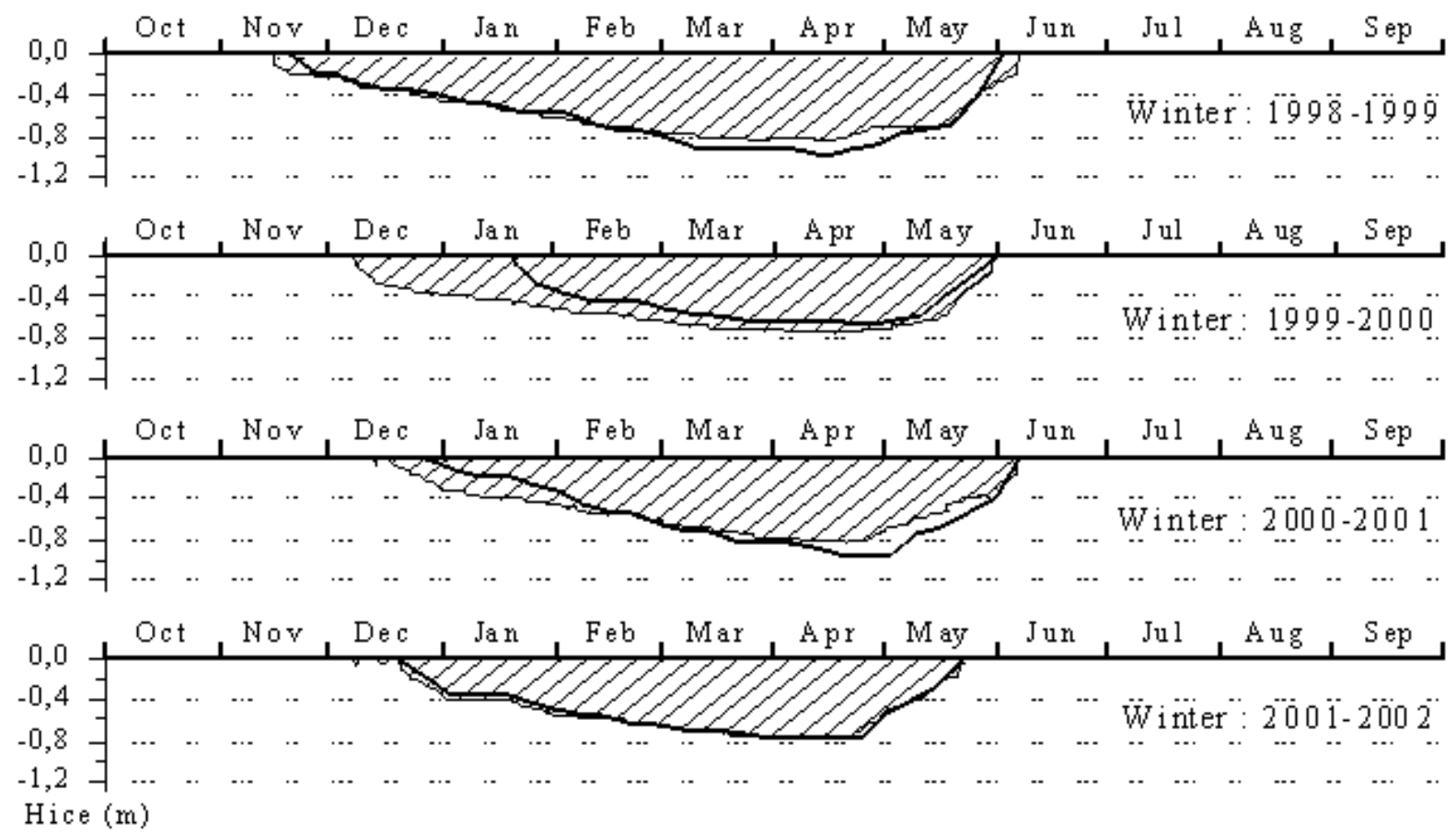

Fig. 5. Calculated ice thickness (filled area) in Akkajaure compared to measured ice thickness from Torne Träsk (thick black line) during four winters. 


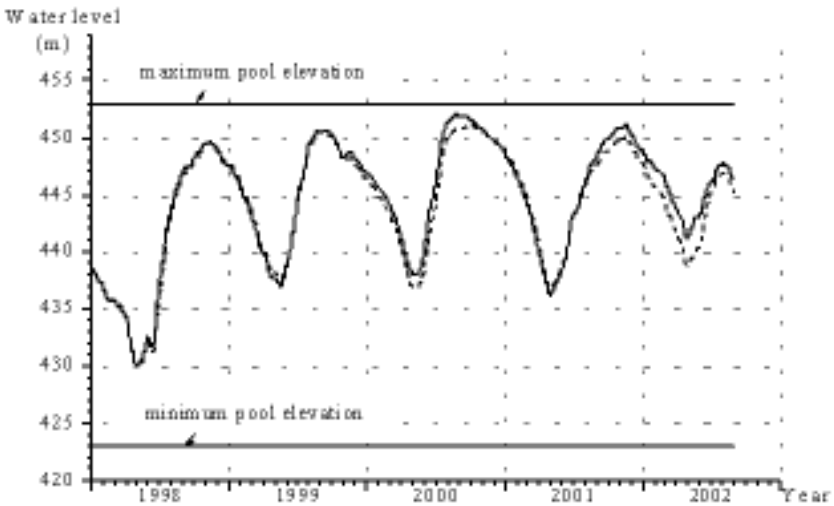

Fig. 6. Measured (black line) and calculated (dashed line) water level in Akkajaure

showed a mean value of $0.8 \mathrm{~m}$ in March, which may be regarded as the typical maximum ice thickness value. In all four winters, the calculated maximum ice thickness is close to $0.8 \mathrm{~m}$, which supports the ice model formulation. Also, in both lakes, the melting dates are almost identical, which confirms that the melting is controlled by the increasing solar radiation in spring.

\section{WATER BALANCE}

The accuracy of modelled lake water levels can be checked against measurements (Fig. 6). In 1998 and 1999, the two curves follow each other closely but, in spring 2000, the calculated level is approximately $1 \mathrm{~m}$ low. This difference persists until winter 2000/2001. In the absence of any systematic difference between the two curves, it has been concluded that the discharge to Akkajaure should not be recalibrated. Comparison of recorded water levels with those calculated by the hydrological model over one year shows a maximum deviation of $2 \mathrm{~m}$, equivalent to a discharge of $16 \mathrm{~m}^{3} \mathrm{~s}^{-1}$. Compared to the yearly mean total discharge (excluding the tunnel flow) of $165 \mathrm{~m}^{3} \mathrm{~s}^{-1}$, this implies a maximum error of $10 \%$.

\section{WATER TEMPERATURE}

The heat content in the reservoir is controlled not only by exchange through the surface but also by the sum of the heat in the river discharge and tunnel inflow, $F_{q}$. If the discharge temperature differs from that in the reservoir, to compare $F_{q}$ and $F_{n e t}$, here defined as the sum of $F_{n}$ and $F_{s}^{w}, F_{q}$, from Eqn.(5), may be reduced to:

$$
F_{q}=\rho * c_{p} * Q_{i n} * D T / \text { Area }
$$

where $Q_{i n}$ is the volume discharge, $D T$ is the temperature

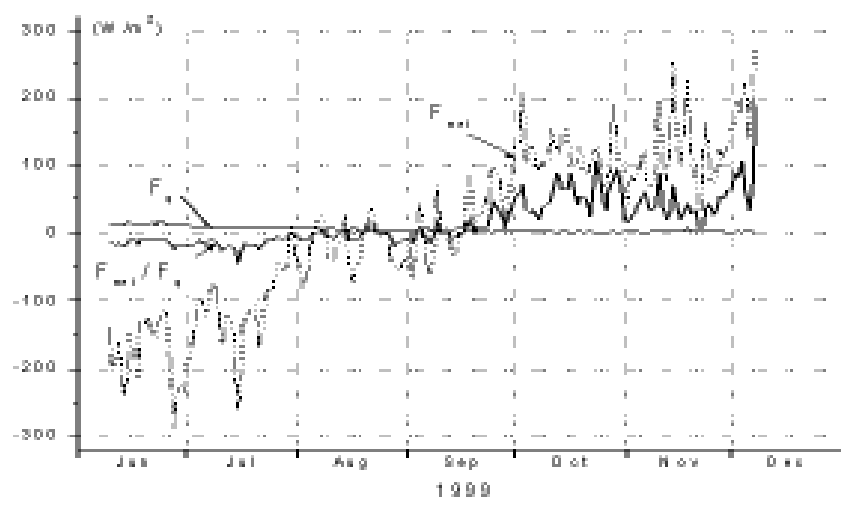

Fig. 7. The relation between the net atmospheric heat flux $F_{n e t}$, and discharge heat flux, $F_{q}$, during the open water season in 1999.

difference between the discharge temperature, $T_{i n}$, and the upper layer reservoir temperature, $\mathrm{T}$ while Area is the actual reservoir surface area. The daily mean values of the fluxes $F_{q}$ and $F_{n e t}$ have been quantified on the assumption that $D T=1^{\circ} \mathrm{C}$ and the result, for the ice free season in 1999 , is shown in Fig. 7. Unfortunately, only a few summer measurements of the discharge temperature are available so the true temperature difference over a whole year is unknown. In Akkajaure, $F_{q}$ will be much smaller than $F_{\text {net }}$ during all ice free months except for August and September when $F_{n e t}$ is changing from an incoming to an outgoing heat flux and, thus, may vary around zero.

To find the sensitivity of the Akkajaure surface temperature to different $D T$ values, test runs were made for $D T$ values of $-1,0,+1$ respectively (Fig. 8); the surface water temperature changed by only $0.2^{\circ} \mathrm{C}$ when $D T$ is $1^{\circ} \mathrm{C}$ so it was assumed that $D T=+1^{\circ} \mathrm{C}$ from June to September and $D T=-1^{\circ} \mathrm{C}$ for the rest of the year. The reason for using different values of $D T$ for different months is that

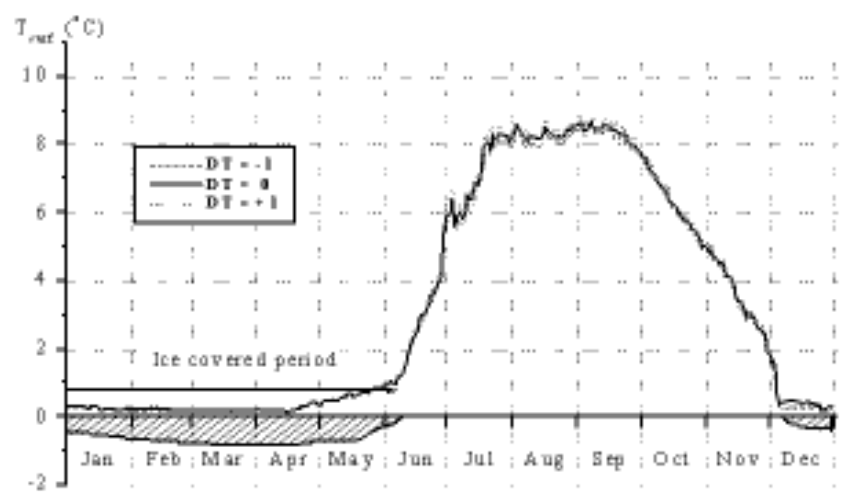

Fig. 8. Calculated surface water temperature and ice thickness in Akkajaure for different DT values during 1999. 

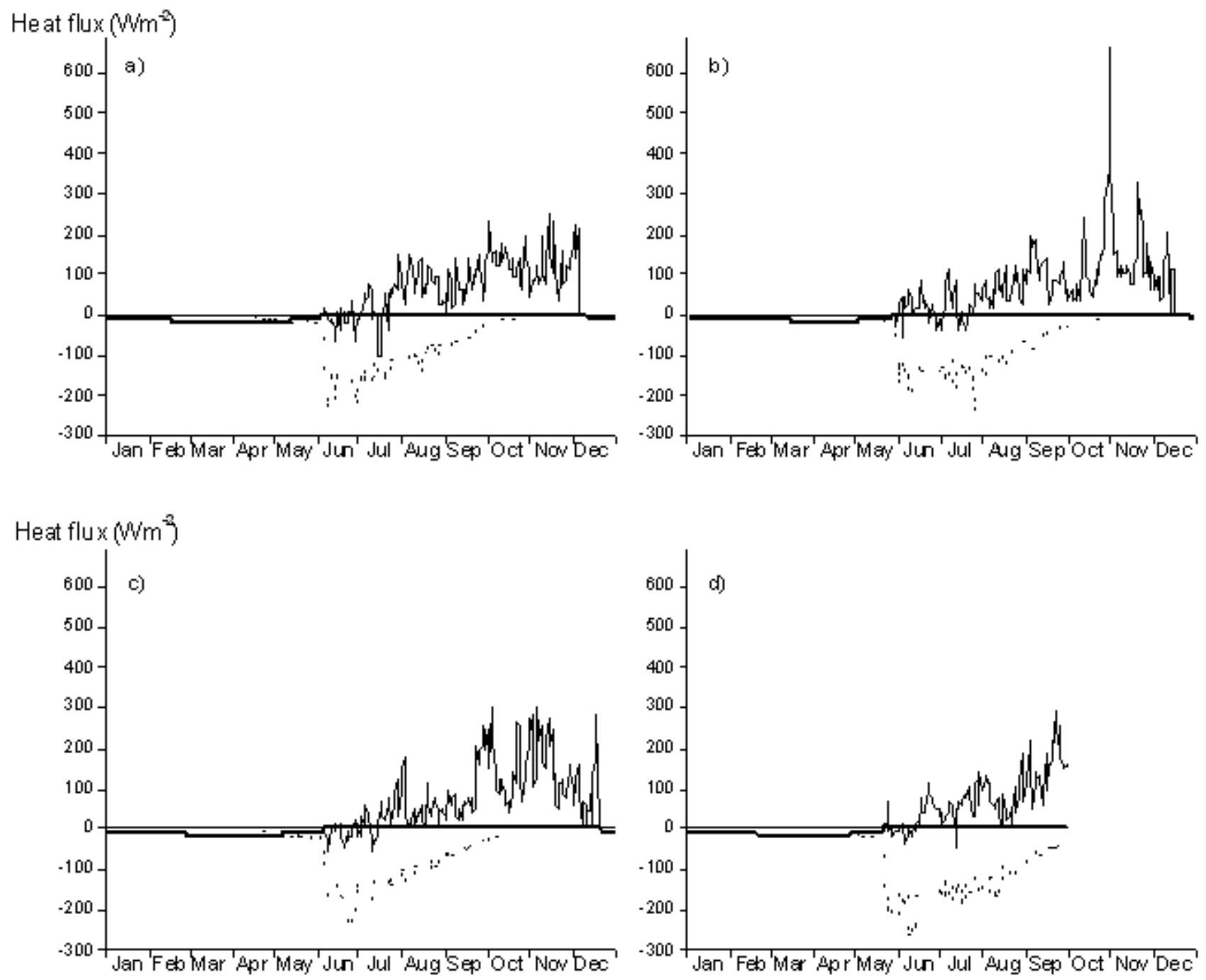

Fig. 9. The figure shows the calculated heat fluxes from the years 1999 (a), 2000 (b), 2001 (c) and 2002 (d). Daily mean values of the sum of the sensible heat flux, latent heat flux and net long wave radiation (black line) and daily mean values of the insolation that penetrates the water surface (dotted line). Positive values describe the water heat loss and negative values the heat gain. The ice cover is marked with a thick black line

during spring and summer the discharge water warms faster than Akkajaure. In autumn and winter the reverse happens.

The temperature development in Akkajaure is almost totally controlled by surface heat fluxes. Daily mean values of the sum of the boundary fluxes i.e. the sensible and latent heat and net long wave radiation are shown in Fig. 9 with daily mean values of short wave radiation. Positive fluxes mean that heat is leaving the water. Insolation dominates the warming period and starts to penetrate the snow and ice cover some two months before the break up date. From late summer to the next ice formation date, the heat loss is dominated by the boundary fluxes. The maximum heat loss occurs in late October 2000 when a loss of approximately $600 \mathrm{w} \mathrm{m}^{-2}$, was caused by a period of low air temperatures of $-9^{\circ} \mathrm{C}$ and strong wind velocities of $17-18 \mathrm{~m} \mathrm{~s}^{-1}$.

An almost constant temperature profile persists under the ice cover until April/May when the insolation becomes large enough to penetrate the snow/ice cover. The water temperature close to the ice surface increases but as all the water under the ice has a temperature below $4^{\circ} \mathrm{C}$, the insolation builds up instabilities and thermal convection starts. The resultant constant temperature layer increases in depth slowly until the ice breaks up and warming occurs from June to August when the surface water temperature peaks at about $10^{\circ} \mathrm{C}$. before cooling from September to December when the next ice formation starts. Figure 10 shows the development of the surface water temperature and ice thickness from 1 January 1998 to 30 September 


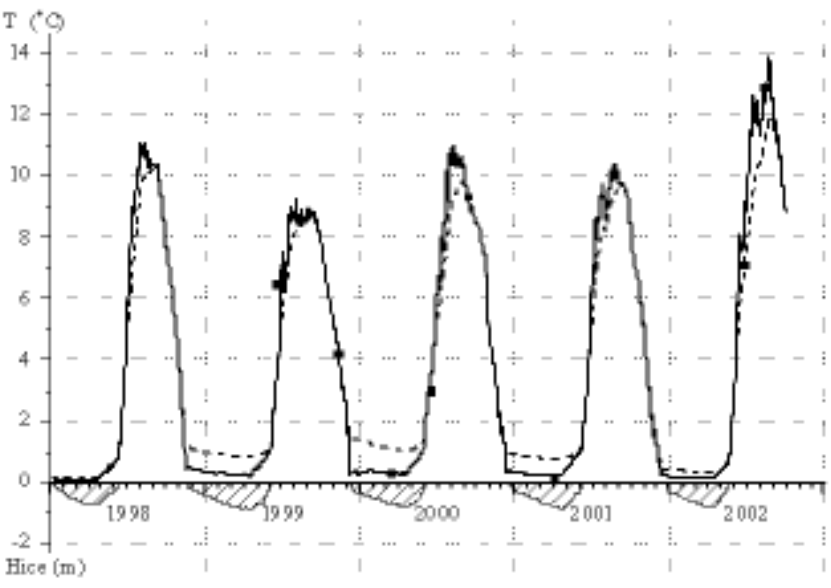

Fig. 10. Calculations of the surface water temperature (black line), the mean water temperature (dashed line) and ice thickness (filled area) in Akkajaure. The nine different surface temperature measurements are marked with black squares.

2002. There is a large inter-annual variation with a maximum surface temperature of $9^{\circ} \mathrm{C}$ in the summer 1999 to $13^{\circ} \mathrm{C}$ in the summer 2002 which is the second warmest summer known in this region, after the summer of 1937, since meteorological measurements began in 1860 (SMHI, 2002). The surface temperature measurements are in good agreement with the calculations except for the measurement in June 1999.
Another way to present the calculated water temperature in Akkajaure is shown in Fig. 11 where both ice, water level and vertical temperature structure is shown from the year 2000. The main warming starts at the ice break up in the end of May when the water mass is well mixed at a temperature around $3^{\circ} \mathrm{C}$. During June and July, the water level rises because of the large discharge and the maximum water temperature is reached at the beginning of August.

A comparison between the measured and calculated temperature profiles is shown in Fig. 12. Added to the figure are the winter (wm) and summer ( $\mathrm{sm}$ ) mean profiles based on the old measurements. As eight of nine profiles agree well, the largest discrepancy between measured and calculated temperature profiles is $0.5-1.0^{\circ} \mathrm{C}$. This provides good support to the assumption is that the lake model simulates Akkajaure heat content over several years with good accuracy without any adjustments. The model fails in simulating the measured profile from 20 June 1999, which shows a thin warm surface layer of $6.5^{\circ} \mathrm{C}$ over a layer of $5^{\circ} \mathrm{C}$ while the simulated profile is a constant $3.5^{\circ} \mathrm{C}$. Is the reason for the warm profile in June that the real water temperature under ice is much warmer than the simulated value? Yet, on April 27, the measured profile agreed well with that simulated as indeed, it does for August 12 when, following the June measurement, the temperature would be expected to be warmer than simulated. Even model tests, using different ice break up dates, have shown that it is not

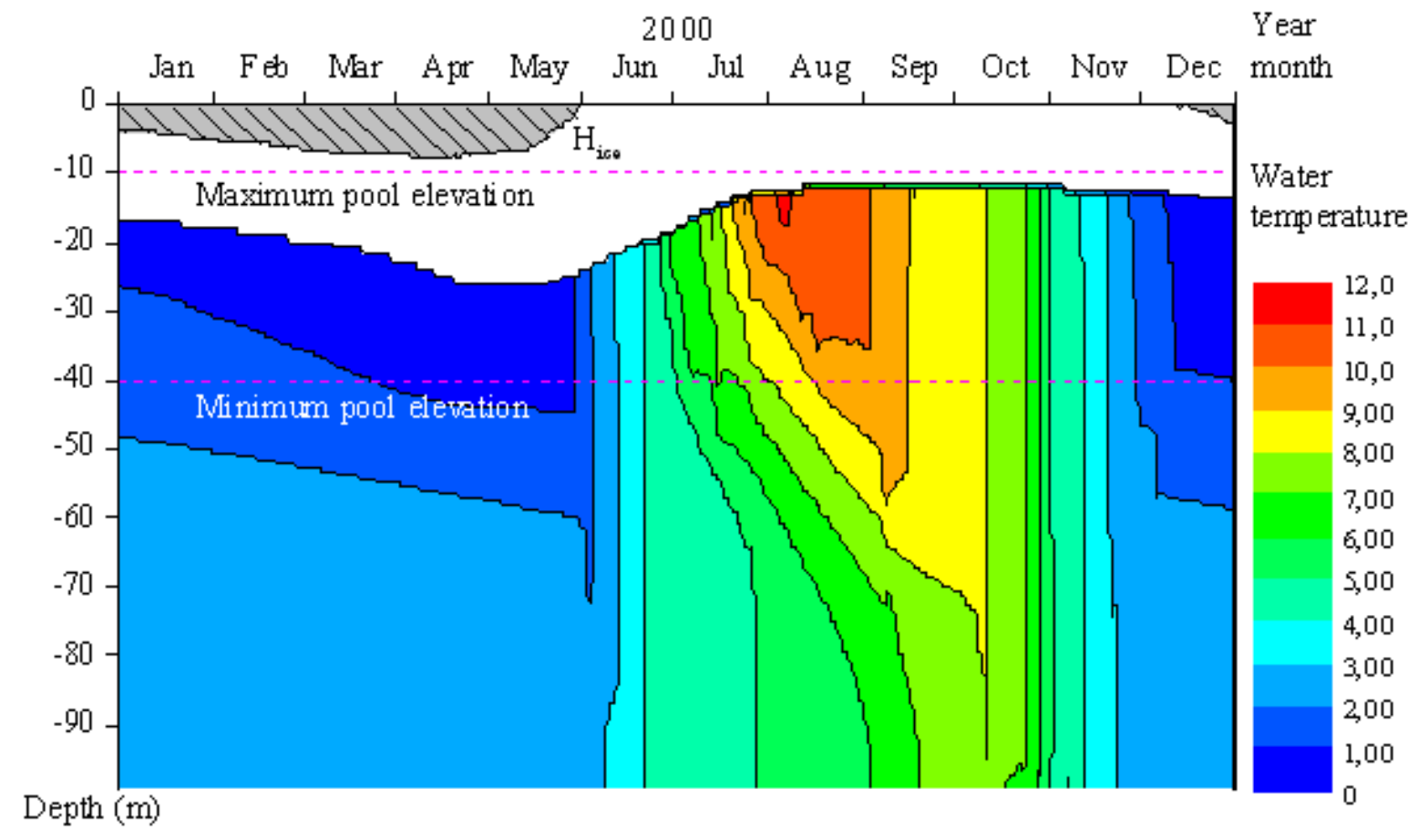

Fig. 11 Development of the water temperature, ice thickness and water level in Akkajaure during the year 2000. (Note that the ice thickness is multiplied by a factor 10). 

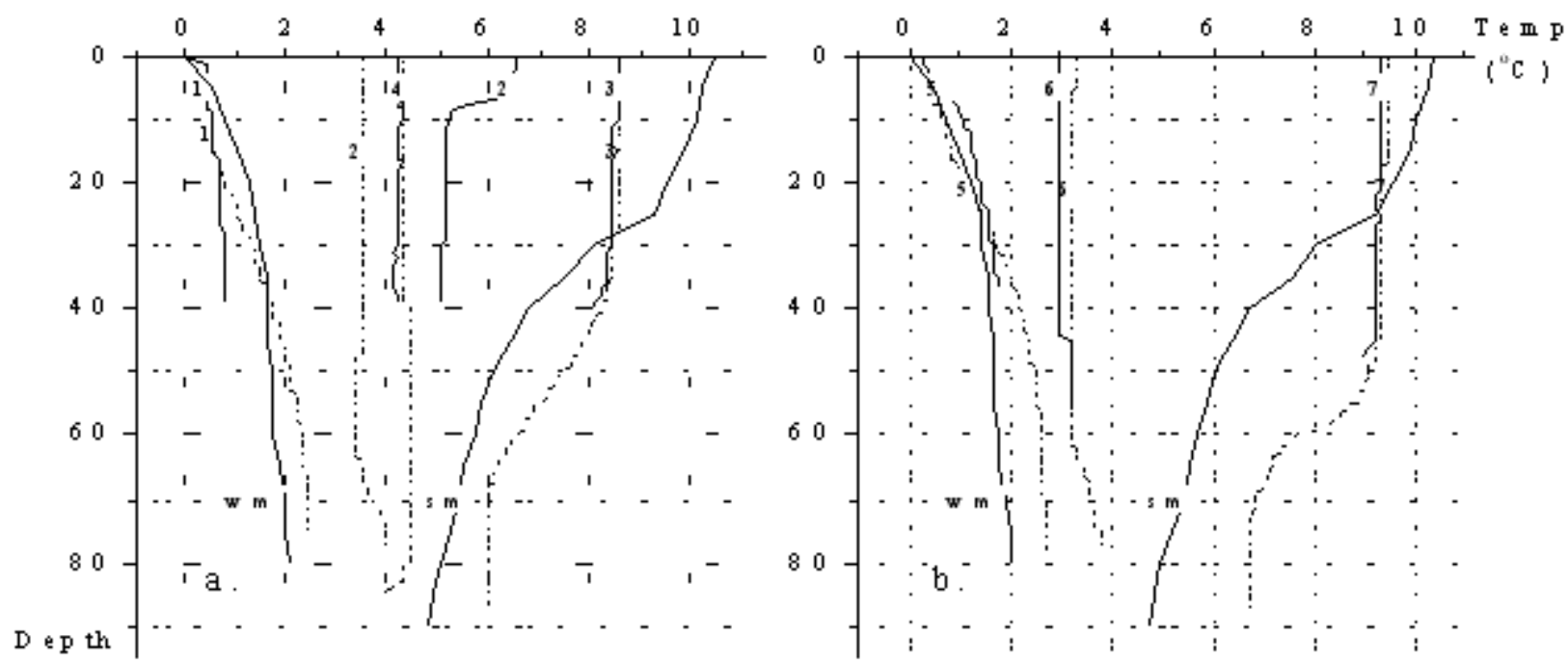

(III)
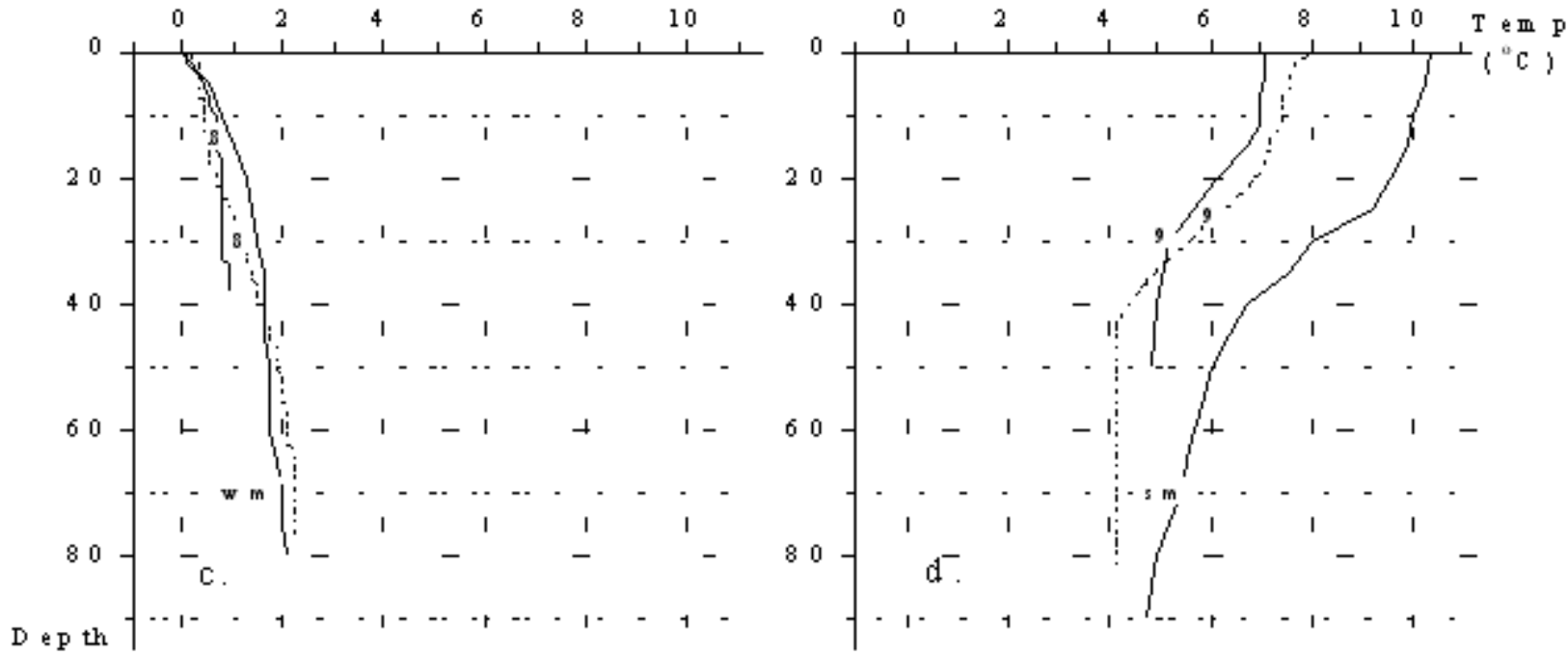

(m)

Fig. 12. Calculated (dotted line) and measured (black line) water temperature profiles in Akkajaure. The thick black lines are the winter and summer mean values. The nine different measurement dates are marked with numbers: $1=1999-04-27,2=1999-06-20,3=1999-08-12,4$ $=1999-11-10,5=2000-03-13,6=2000-06-14, \quad 7=2000-09-08, \quad 8=2001-04-02, \quad 9=2002-06-24$.

possible to reproduce the measured warm profile. The conclusion must be that the measured profile from 20 June 1999 is not representative of the temperature conditions.

The two basic questions asked in the introduction are still not answered. Firstly, is Akkajaure stratified during the summer and secondly, what effect has the large regulation on the temperature structure? The first question requires a definition of a stratified reservoir. How strong must stratification be to prevent wind induced mixing from reaching the bottom layer? Of course, this depends on the strength of the mixing i.e. the wind stress. How important is the extinction coefficient, $\beta$, for the temperature development and stratification in Akkajaure? Model tests were performed with seven different $\beta$ values ranging from 0.1-1.0. All calculations were performed under the following definition of the stratification, $\frac{\partial \rho}{\partial z} \geq 0.015$. This is a weak stratification. It corresponds to a temperature difference of only $3{ }^{\circ} \mathrm{C}$ in the temperature interval $6-10^{\circ} \mathrm{C}$, over a layer depth of $10 \mathrm{~m}$. Table 2 shows that the number of stratified days for the different $\beta$ values including the original result with the measured $\beta$ values, is almost the same in all calculations except when $\beta$ equals 0.1 which is an unrealisticly low value for Akkajaure. This result is quite surprising as it is common knowledge that $\beta$ normally has a large impact on the summer water temperature in the surface layer. Another way to investigate the model sensivity for $\beta$ 
Table 2. The number of days when Akkajaure is stratified for different extinction coefficients $(\beta)$.

\begin{tabular}{llllll}
\hline$\beta$ & 1998 & 1999 & 2000 & 2001 & 2002 \\
\hline 0.1 & 10 & 2 & 2 & 2 & 28 \\
0.2 & 18 & 1 & 4 & 5 & 42 \\
0.3 & 15 & 0 & 8 & 7 & 46 \\
0.4 & 15 & 1 & 6 & 10 & 42 \\
0.6 & 17 & 1 & 7 & 7 & 42 \\
0.8 & 15 & 1 & 7 & 8 & 36 \\
1.0 & 13 & 1 & 4 & 10 & 37
\end{tabular}

According

$\begin{array}{llllll}\text { to measurements } & 17 & 1 & 9 & 6 & 48\end{array}$

is to look at the surface water temperature when $\beta$ is 0.2 and 1.0 respectively. The difference between the two calculated surface temperatures is, as a mean during the three summer months, only $0.10^{\circ} \mathrm{C}$ in the cold summer 1999 and $0.31^{\circ} \mathrm{C}$ in the warm summer 2002. Thus, the effect of different $\beta$ values, in the interval $0.2-1.0$, is rather small in Akkajaure both regarding to the number of stratified days and surface water temperature. The conclusion is that the calculated temperature conditions will be almost the same for all $\beta$ values in the interval $0.2-1.0$. The reason is probably the late ice break-up date combined with a rather weak summer warming due to the climate in the mountains in high latitudes in Sweden. The warming will not have time to increase the surface layer temperature to an extent where the buoyancy is large enough to resist wind induced mixing. Using the real $\beta$ values, found from light measurements, there is only one day with a stratification larger than 0.015 $\left(\mathrm{kg} \mathrm{m}^{-3}\right)$ in 1999 and 48 days in 2002. The stratification depths and dates for all five years are shown in Fig. 13. As a rough estimate, Akkajaure has a weak stratification in only one to two weeks a year (excluding the extremely warm summer 2002).

The second question to be answered deals with the large regulation of Akkajaure. Does a varying water surface favour warming and the temperature structure? A test calculation at a constant high water level where the dam outflow equals the sum of all inflows, i.e. no regulation, found that compared to the normal regulated case, the maximum surface water temperature was $1-2^{\circ} \mathrm{C}$ cooler; the mean depth of Akkajaure, during the warming months, is smaller in the regulated case and thus the warming is faster. Temperature profiles from both the regulated and non-regulated case, from the same dates as the measurements, are shown in Fig. 14. Clearly, regulation of the Akkajaure favours warming

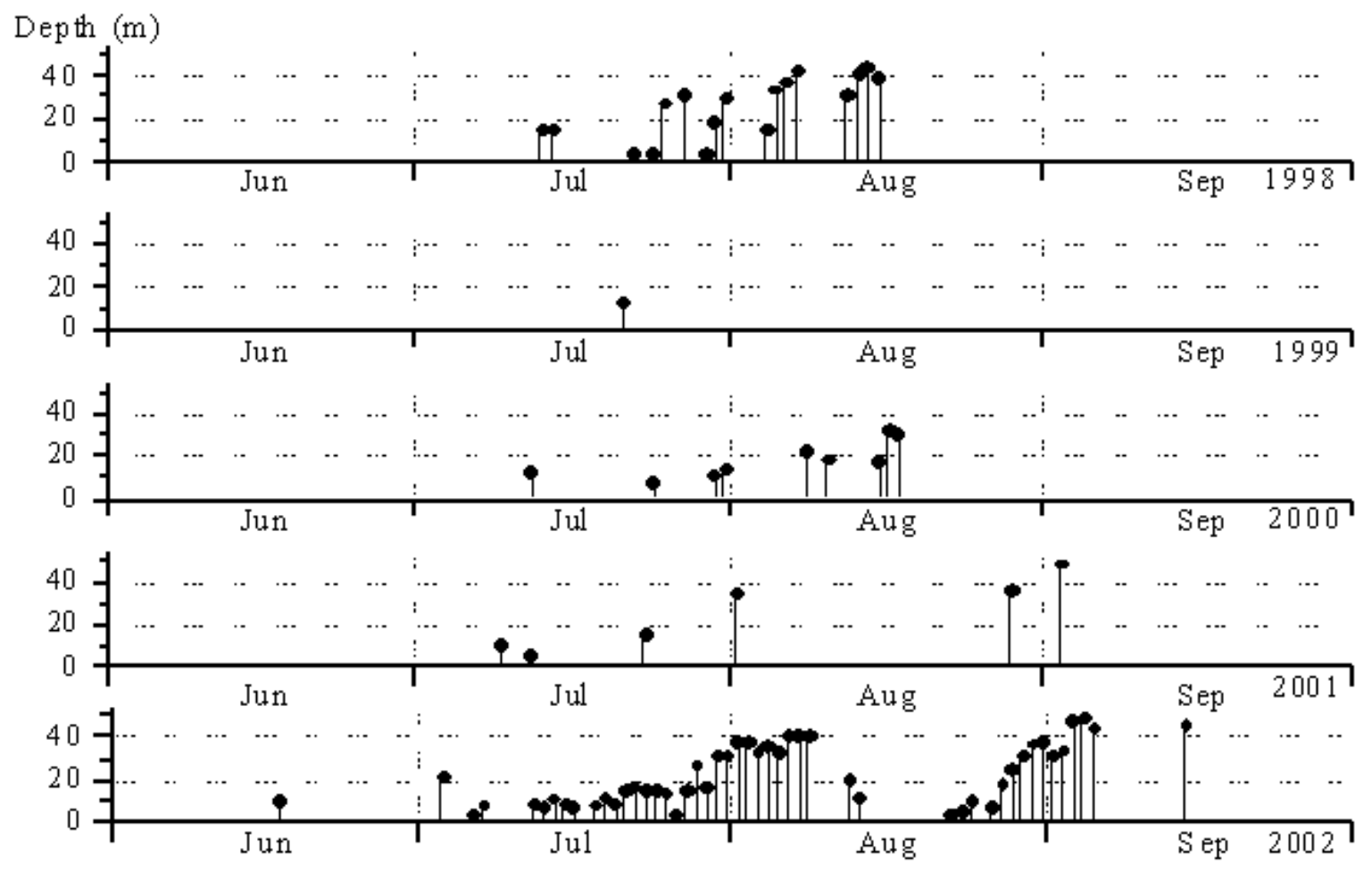

Fig. 13. The black dots mark the days and depths when Akkajaure has a weak stratification during the summers $1998-2002$. 


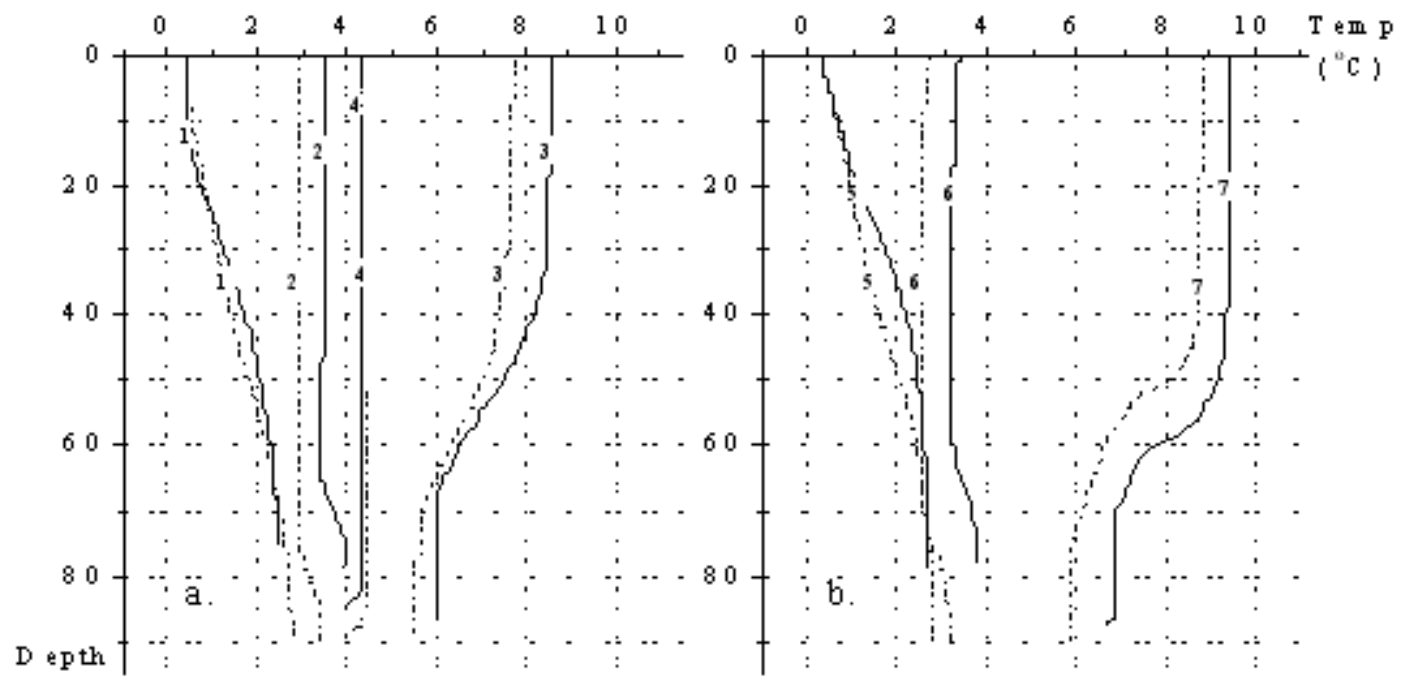

(in )

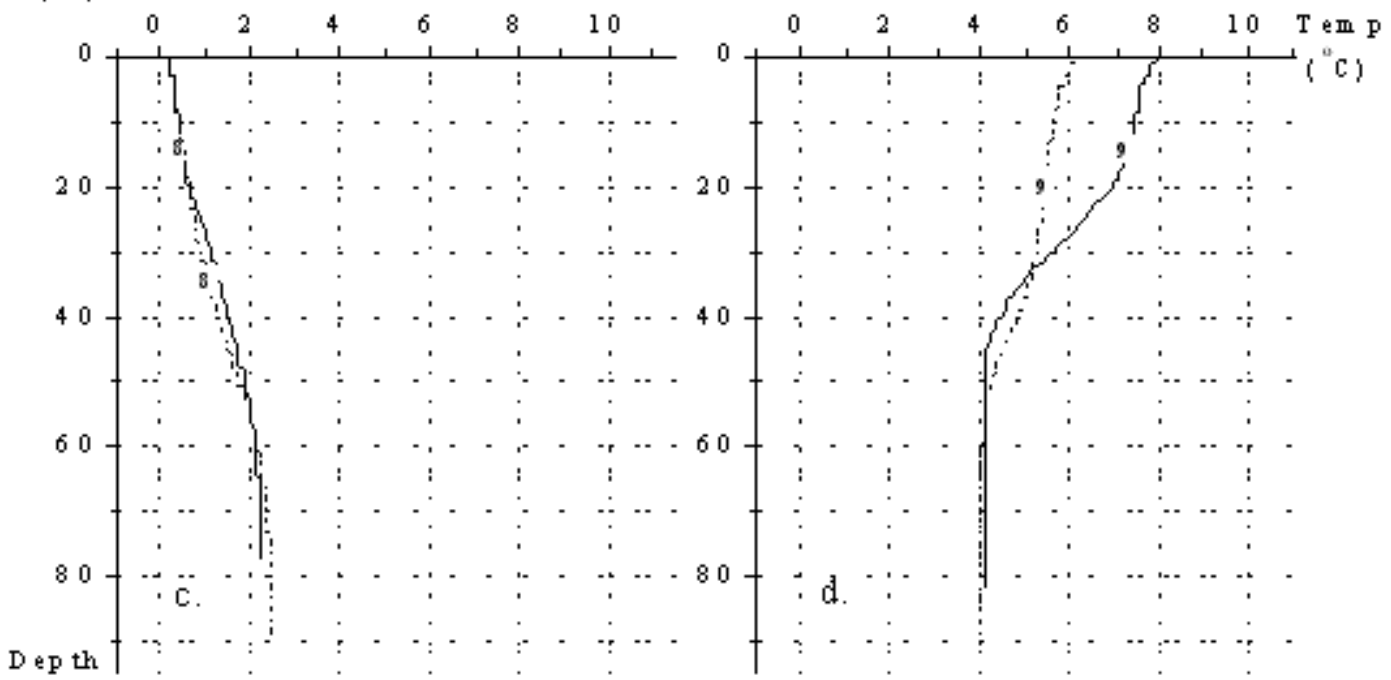

(II)

Fig. 14. A comparison between calculated water temperature profiles in Akkajaure under regulated (black line) and non-regulated (dotted line) conditions. The nine different dates are marked with numbers: $1=1999-04-27,2=1999-06-20,3=1999-08-12, \quad 4=1999-11-10,5=$ $2000-03-13, \quad 6=2000-06-14, \quad 7=2000-09-08, \quad 8=2001-04-02, \quad 9=2002-06-24$.

and stratification; the larger the regulation, the warmer and more stratified Akkajaure becomes.

\section{Discussion and conclusion}

Over a year, the total discharge to Akkajaure peaks following snow melt in May and June and again following heavy rainfall in autumn. The spring melt water fills the reservoir from the low winter level to a level close to the maximum pool elevation, which may represent more than $70 \%$ of the total reservoir volume. Light measurements indicate that the spring discharge transports sediment into Akkajaure; this changes the optical properties of the water but not the temperature conditions. The lake model describes all temperature profiles but one with good accuracy. The largest discrepancy between measured and calculated temperature profiles is $0.5-1.0^{\circ} \mathrm{C}$. As the measured profiles do not reach into the deeper layers it is not possible to decide if the hypolimnetic mixing formulation is valid or not. Hence, the calculated bottom temperature profile was compared with the mean profile of the old winter and summer temperature measurements. The discrepancy in the bottom water also proved to be $0.5-1.0^{\circ} \mathrm{C}$, which supports the deep water mixing formulation. Despite the shortage of measured temperature profiles, it must be concluded that the lake model is able to calculate the temperature profiles in 
Akkajaure over several years with good accuracy.

In what way will the regulation affect the temperature structure? A test calculation was performed with a constant maximum water level where all river inflows were equal to the dam outflow i.e. no regulation. The result, which was compared to the regulated case with large water level variations, showed that the maximum water temperature in the regulated case became $1-2^{\circ} \mathrm{C}$ warmer compared to the non-regulated case. The explanation is that the mean depth of Akkajaure is smaller in the regulated case and thus it is warmed faster. It is quite interesting that the Akkajaure regulation works in favour of the warming and stratification. A conclusion may be that the larger the regulation becomes the warmer the reservoir becomes.

Is Akkajaure stratified or not during the summer? In every summer the maximum water temperature occurs in August. The maximum calculated summer value varied between $9-13^{\circ} \mathrm{C}$ during the five summers of $1998-2002$. The main reason for low temperature values are the high latitude with low altitude of the sun, low air temperatures and a late ice break-up date. Thus, the water mass may not receive enough heat to develop a warm surface layer with a typical thermocline during the summer. This affects also the vertical temperature structure in that only weak stratifications may occur in Akkajaure. Such a weak stratification as occurred on only one day in July in the cold summer of 1999, is likely to occur on only one to two weeks a year and the stratified days will not be consecutive.

\section{Acknowledgement}

This work has been sponsored by the Swedish Natural Science Research Council and the Swedish Meteorological and Hydrological Institute. Thanks are due to Vattenfall and Hans Lindmark for the use of their facilities in Ritsem for field studies, to Erik Smedberg and Sture Hansson for providing the echo sounder to find the bottom of the reservoir and to Jenni Brink and Elinor Arsam for valuable contributions in the field.

\section{References}

Bengtsson, L. and Svensson, T., 1996. Thermal regime of ice covered Swedish lakes. Nord. Hydrol., 27, 39-56.

Bodin, S., 1979.A predictive numerical model of the atmospheric boundary layerbased on a turbulent energy equation. Report Meteorology and Climatology No. 13, SMHI, SE-601 76 Norrköping, Sweden.

Eklund, A., 1998. Ice thickness in lakes in Sweden. (Istjocklek på sjöar- en statistisk bearbetning av SMHIs mätningar.) SMHI Hydrologi $\mathrm{Nr} 76$ (in Swedish).

Forsgren, N. 1989. The energetic river. (Den effektfulla Älven.) Vattenfall Norrbotten. ISBN 91-7186-282X (in Swedish).

Gosink, J. P., 1987. Northern lake and reservoir modeling. Cold Reg. Sci.Technol., 13, 281-300.

Hondzo, M. and Stefan, H.G., 1993. Lake Water Temperature Simulation Model. J. Hydraul. Eng., 119, 11251-1273.

Lindström, G., Johansson,B., Persson, M., Gardelin, M. and Bergström, S., 1997. Development and test of the distributed HBV-96 hydrological model. J. Hydrol., 201, 272-288.

Moberg, A., 1981. Temperature measurements in Swedish lakes. (Mätningar av sjötemperatur vid SMHI). SMHI HB Rapport Nr. 45.

Omstedt, A. and Axell, L., 2003. Modelling the variations of salinity and temperature in the large Gulfs of the Baltic Sea. Contl Shelf Res., .23, 26-294.

Rodi, W., 1980. Turbulence models and their application in hydraulics - a state of the art review. International Association for Hydraulic Research (IAHR), Delft, The Netherlands.

Sahlberg, J., 1983. A hydrodynamical model for calculating the vertical temperature profile in lakes during cooling. Nord. Hydrol., 14, 239-254.

Sahlberg, J., 1988. Modelling the Thermal Regime of a Lake During the Winter Season. Cold Reg. Sci. Technol., 15, 151159.

SMHI, 1996. A register of Swedish lakes. ( Svenskt sjöregister.) Volym 1 and 2, 1996 (in Swedish).

SMHI, 2002. Weather and water. (Väder och Vatten.) SMHI, Nr 9 (in Swedish).

Svensson, U., 1998. Probe, Program for Boundary Layers in the Environment. System description and Manual.. SMHI RO Report No.24, Swedish Meteorological and Hydrological Institute, Norrköping.

U.S Army Coastal Engineering Research Center, 1977. Shore protection manual. Volume 1, third edition, US Government Printing Office, Washington D.C., USA. 